\title{
Hubungan antara Pengetahuan, Sikap dan Perilaku Pencegahan HIV/ AIDS pada Siswa SMPN 251 Jakarta
}

\author{
Relationship between Knowledge, Attitudes and Behavior regarding HIVI \\ AIDS Prevention in Students of 251 State Junior High School Jakarta
}

\author{
Maria Angela ${ }^{1}$, Sondang R. Sianturi ${ }^{2}$, Sudibyo Supardi ${ }^{3}$ \\ ${ }^{1)}$ Mahasiswa Keperawatan STIK St. Carolus, Jalan Salemba Raya No. 41, Paseban, Kecamatan Senen, Jakarta 10440 , \\ Indonesia \\ ${ }^{2)}$ Staf Pengajar Keperawatan STIK St. Carolus, Jalan Salemba Raya No. 41, Paseban, Kecamatan Senen, Jakarta 10440 , \\ Indonesia \\ 3) Pusat Penelitian dan Pengembangan Sumber Daya dan Pelayanan Kesehatan, Jalan Percetakan Negara No. 29 Jakarta \\ 10560, Indonesia \\ Korespondensi: myfi.angel@yahoo.com
}

Submitted: 7 Mei 2019, Revised: 2 Agustus 2019, Accepted: 19 Agustus 2019

https://doi.org/10.22435/jpppk.v3i2.1943

\begin{abstract}
Abstrak
HIVIAIDS merupakan penyakit menular yang memiliki angka kejadian tinggi di dunia. Hal ini disebabkan masih rendahnya pengetahuan, informasi dan kesadaran masyarakat tentang penyakit HIVIAIDS, masih adanya stigma sosial dan diskriminasi, keterbatasan tenaga konselor atau psikolog, dan keterbatasan sosialisasi di daerah terpencil. Tujuan penelitian ini untuk mengetahui hubungan antara pengetahuan, sikap dan perilaku pencegahan HIVIAIDS pada siswa/siswi SMPN 251 Jakarta. Penelitian ini menggunakan rancangan kuantitatif potong lintang. Sampel penelitian mencakup semua siswa-siswi kelas VIII berjumlah 139 sampel dengan teknik total sampling. Hasil penelitian menunjukkan persentase terbesar siswa-siswi memiliki pengetahuan HIVIAIDS yang baik $(95,3 \%)$, sikap positif $(95 \%)$ dan perilaku pencegahan baik $(95 \%)$. Tidak terdapat hubungan yang bermakna antara pengetahuan dan perilaku pencegahan HIVIAIDS, tetapi terdapat hubungan yang bermakna antara sikap dan perilaku pencegahan HIVIAIDS pada siswa/siswi SMPN 251 Jakarta.
\end{abstract}

Kata kunci: HIVIAIDS, pengetahuan, sikap dan perilaku pencegahan, siswa SMP

\begin{abstract}
HIVIAIDS is a communicable disease that has a high incidence in the world. This is due to the low level of knowledge, information and public awareness about HIV/ AIDS, social stigma and discrimination, limited counselors or psychologists, and limited socialization in remote areas. The purpose of this study was to determine the relationship between knowledge, attitudes, and behaviors of HIVIAIDS prevention among students of SMPN 251 (State Junior High School) Jakarta. This study used a cross-sectional quantitative design. The study sample included all students of class VIII totaling 139 samples with a total sampling technique. The results showed the largest percentage of students had good knowledge of HIVIAIDS (95.3\%), positive attitude (95\%) and good prevention behavior (95\%). There was no significant relationship between HIVIAIDS prevention knowledge and behavior, but there was a significant relationship between HIVIAIDS prevention attitudes and behavior in students of SMPN 251 Jakarta.
\end{abstract}

Keywords: knowledge, attitudes, prevention behavior, HIV/ AIDS, junior high school 


\section{Pendahuluan}

Peraturan Menteri Kesehatan RI No. 21

Tahun 2013 tentang Penanggulangan HIV dan AIDS menyatakan Human Immunodeficiency Virus (HIV) adalah virus yang menyebabkan Acquired Immuno Deficiency Syndrome (AIDS). AIDS adalah suatu kumpulan gejala berkurangnya kemampuan pertahanan diri yang disebabkan oleh masuknya virus HIV dalam tubuh seseorang. Program penanggulangan HIV/AIDS terdiri atas promosi kesehatan, pencegahan penularan HIV, pemeriksaan diagnosis HIV, pengobatan, perawatan, dan dukungan serta rehabilitasi. Promosi kesehatan ditujukan untuk meningkatkan pengetahuan yang benar dan komprehensif mengenai pencegahan penularan HIV serta menghilangkan stigma dan diskriminasi. ${ }^{1}$

WHO (World Health Organization) pada tahun 2017 melaporkan ada 36.900 .000 orang yang hidup dengan HIV positif, sekitar 2,1 juta adalah anak-anak ( $<15$ tahun). UNAIDS atau (Joint United Nations Programme on HIV and AIDS) menyatakan bahwa anak-anak yang baru terkena infeksi HIV pada usia 15-19 tahun ada 35.000 laki-laki dan 97.000 perempuan. Anak-anak yang hidup dengan HIV positif usia 10-19 tahun ada 450.000 laki-laki dan 580 perempuan. Jumlah kematian anak usia 10-19 tahun karena AIDS ada 11.000 laki-laki dan 9.300 perempuan. $^{2}$

Kemenkes melaporkan data jumlah penderita AIDS di Indonesia sejak bulan Januari hingga Maret 2017 sebanyak 673 orang untuk kelompok umur 10-29 tahun (29,3\%). Sementara untuk golongan umur 5-14 tahun dan 15-19 tahun, persentase infeksi HIV yang dilaporkan dalam kurun waktu yang sama masing-masing sekitar $1 \%$ atau sebanyak 102 orang dan sekitar 3,2\% atau sebanyak 334 orang. ${ }^{3}$

Dilaporkan bahwa hingga Juni 2017 terdapat lebih dari 255.000 kasus kejadian HIV di Indonesia. Sebanyak $72,4 \%$ kejadian tersebut akibat hubungan seksual yang tidak terproteksi. ${ }^{4}$ Laporan Perkembangan HIV/AIDS Ditjen Pengendalian Penyakit dan Penyehatan Lingkungan Kemenkes RI, Triwulan 2 tahun 2017 menyebutkan, jumlah orang yang terinfeksi HIV sebanyak 23.204. Jumlah ini mencakup 14.970 laki-laki dan 8.234 perempuan. ${ }^{5}$

Prevalensi HIV dan AIDS di wilayah DKI
Jakarta mengalami peningkatan dari tahun 2016 sampai tahun 2017. Kasus HIV di DKI Jakarta mencapai 4.660 orang tahun 2016, meningkat menjadi 6.562 orang tahun 2017. Kasus AIDS pada tahun 2016 mencapai 545 orang dan tahun 2017 meningkat menjadi 576 orang. Kebanyakan kasus tersebut terjadi pada mereka yang berusia produktif 21-29 tahun. ${ }^{6}$

Jumlah penderita AIDS dari kalangan anak sekolah yang dilaporkan di DKI Jakarta bulan Januari-Maret 2017 sebanyak 14 orang. Secara umum di wilayah Jakarta Timur jumlah kasus HIV tahun 2017 ada sekitar 295 orang, sedangkan jumlah kumulatif kasus AIDS hingga 2017 ada sekitar 411 orang. ${ }^{3}$

Usia remaja adalah kelompok usia berisiko tinggi mengalami HIV/AIDS karena pada usia ini anak-anak sedang mencari jati diri dengan cara mencoba hal baru. Atas dasar tersebut, peneliti tertarik untuk meneliti upaya pencegahan HIV/ AIDS pada remaja usia anak SMP. Lokasi penelitian di SMPN 251 Jakarta karena berdekatan dengan lingkungan prostitusi. Hal ini dianggap penting karena apabila perilaku remaja buruk atau mengarah kepada perilaku yang berakibat remaja itu terkena HIV/AIDS, perlu upaya peningkatkan pengetahuan dan sikap remaja mengenai HIV/AIDS yang benar sejak dini agar jumlah penderita HIV/AIDS pada remaja tidak meningkat terus.

Penelitian belum pernah dilakukan untuk mengetahui perilaku pencegahan HIV/AIDS dan apakah ada hubungan antara pengetahuan, sikap dan perilaku pencegahan HIV/AIDS pada siswa/siswi SMPN 251 Jakarta. Dengan alasan tersebut, maka tujuan penelitian adalah mengetahui hubungan antara pengetahuan, sikap dan perilaku pencegahan HIV/ AIDS pada murid SMPN 251 Jakarta. Penelitian ini diharapkan dapat menjadi data dasar untuk promosi pencegahan HIV/AIDS pada siswa sekolah tersebut.

Penelitian Rahmawati et al (2014) di kota Yogyakarta menunjukkan, pengetahuan murid SMA Taman Madya Jetis Yogyakarta tentang HIV/AIDS tergolong tinggi (48\%). ${ }^{7}$ Sementara sikap terhadap pencegahan HIV/AIDS mayoritas cukup (66\%).

Penelitian Tampi, et al (2013) di kota Manado menunjukkan, mayoritas siswa-siswi SMA Manado International School sudah berpengetahuan 
baik tentang tindakan pencegahan HIV/AIDS (70\%) dan bersifat positif $(64,2 \%)$.

\section{Metode}

Penelitian dilakukan di DKI Jakarta karena provinsi ini merupakan kota ketiga terbesar yang terinfeksi HIV (1.403 orang), setelah Jawa Timur (1.614 orang) dan Jawa Barat (1.505 orang). Namun, menjadi terbesar yang menderita AIDS (121 orang) pada bulan Januari hingga Maret 2017. ${ }^{3}$ SMPN 251 Jakarta berlokasi dekat dengan daerah tempat prostitusi, sehingga peneliti tergerak melakukan penelitian untuk melihat pengetahuan, sikap dan perilaku pencegahan HIV/AIDS di SMPN 251 Jakarta.

Penelitian dirancang secara cross sectional. Populasi penelitian adalah murid kelas VIII SMPN 251 Jakarta pada November 2018 sebanyak 210 responden. Jumlah sampel penelitian sebesar 139 responden, yang dihitung dengan rumus Slovin. Pengambilan sampel dilakukan secara simple random sampling. Data dikumpulkan menggunakan kuesioner/angket yang berisi pertanyaan terkait tentang pengetahuan, sikap dan tindakan pencegahan HIV/AIDS. Definisi operasional variabel yang digunakan sebagai berikut.

1. Pengetahuan merupakan hasil tahu seseorang, seperti mata, hidung, telinga, dsb. Pengetahuan dikategorikan menjadi: ${ }^{8}$

Tinggi, bila total nilai $\geq$ median;

Rendah, bila total nilai $<$ median.

2. Sikap merupakan respon tertutup seseorang terhadap stimulus yang diterimanya, yang melibatkan faktor pendapat dan emosi yang bersangkutan (senang-tidak senang, setujutidak setuju, baik-tidak baik, dsb). Sikap dibuat kategori menjadi: 8

Positif, bila total nilai $\geq$ median;

Negatif bila total nilai $<$ median.

3. Perilaku pencegahan adalah respon bersifat positif dan negatif seseorang terhadap stimulus atau objek yang diberikan dan saling berhubungan dengan unsur perilaku pencegahan. ${ }^{8,9}$

Perilaku baik, bila total nilai $\geq$ median

Perilaku kurang baik, bila total nilai $<$ median

Analisis data untuk menilai hubungan

2 variabel skala nominal menggunakan uji ChiSquare.

\section{Hasil}

Karakteristik, pengetahuan, sikap dan perilaku pencegahan HIV/AIDS serta hubungannya dengan perilaku pencegahan HIV/AIDS diuraikan dalam Tabel 1.

Tabel 1 menunjukkan, persentase terbesar responden adalah laki-laki $(55,4 \%)$, berusia 14 tahun (58,3\%), memiliki pengetahuan tinggi (93,5\%), memiliki sikap positif (95\%), dan perilaku pencegahan HIV/AIDS baik $(95,0 \%)$.

Tabel 1. Karakteristik Responden, 2019

\begin{tabular}{lcc}
\hline Karakteristik Murid & Jumlah & Persen (\%) \\
\hline Jenis Kelamin & & \\
Laki-laki & 77 & 55,4 \\
Perempuan & 62 & 44,6 \\
Usia & & \\
12 & 4 & 2,9 \\
13 & 32 & 23,0 \\
14 & 81 & 58,3 \\
15 & 22 & 15,8 \\
Pengetahuan & & \\
Tinggi & 130 & 93,5 \\
Rendah & 9 & 6,5 \\
Sikap & & \\
Positif & 132 & 95,0 \\
Negatif & 7 & 5,0 \\
Perilaku & & \\
Baik & 132 & 95,0 \\
Kurang baik & 7 & 5,0 \\
\hline
\end{tabular}

Sementara Tabel 2 menunjukkan, mayoritas responden memahami, pengertian, penularan, pencegahan, stigma, dan pengobatan HIV/AIDS. Namun, menghindari penggunaan kamar mandi umum karena khawatir telah digunakan oleh penderita HIV/AIDS (66,9\%) dan menghindari bersalaman dengan penderita HIV/AIDS $(51,8 \%)$ masih belum dipahami.

Tabel 3 menunjukkan bahwa siswa-siswi dengan pengetahuan tinggi yang berperilaku pencegahan HIV/AIDS baik 100\%. Hasil uji ChiSquare didapat $\rho$ value $=1,000(>0,05)$, disimpulkan tidak terdapat hubungan yang bermakna antara pengetahuan dan perilaku siswa dalam pencegahan HIV/AIDS. Tabel 3 juga menunjukkan bahwa siswa dengan sikap positif yang memiliki perilaku pencegahan HIV/AIDS baik (98,5\%), sedangkan siswa dengan sikap negatif memiliki perilaku 
Tabel 2. Sebaran Perilaku Pencegahan HIV/AIDS pada Siswa SMPN 251 Jakarta, 2019

\begin{tabular}{|c|c|c|c|c|}
\hline \multirow{2}{*}{ Pernyataan } & \multicolumn{2}{|c|}{ Ya } & \multicolumn{2}{|c|}{ Tidak } \\
\hline & Jumlah & $\%$ & Jumlah & $\%$ \\
\hline \multicolumn{5}{|l|}{ Mencari informasi tentang HIV/AIDS: } \\
\hline - kepada petugas kesehatan & 135 & 97,1 & 4 & 2,9 \\
\hline - melalui media elektronik (internet) & 135 & 97,1 & 4 & 2,9 \\
\hline - melalui media cetak (buku, Koran dll) & 127 & 91,4 & 12 & 8,6 \\
\hline Mengikuti penyuluhan kesehatan tentang pencegahan HIV/AIDS & 135 & 97,1 & 4 & 2,9 \\
\hline $\begin{array}{l}\text { Membantu menyebarluaskan informasi tentang HIV/AIDS di lingkungan } \\
\text { rumah }\end{array}$ & 134 & 96,4 & 5 & 3,6 \\
\hline Menghindari perilaku berisiko: & 60 & 43,2 & 79 & 56,8 \\
\hline - berhubungan seksual sebelum menikah: & 127 & 91,4 & 12 & 8,6 \\
\hline $\begin{array}{l}\text { - menggunakan kamar mandi umum karena khawatir telah dipakai oleh } \\
\text { penderita HIV/AIDS }\end{array}$ & 93 & 66,9 & 46 & 33,1 \\
\hline - bersalaman dengan penderita HIV/AIDS; & 72 & 51,8 & 67 & 48,2 \\
\hline Menjauhi teman/ keluarga anda yang menderita HIV/AIDS; & 60 & 43,2 & 79 & 56,8 \\
\hline Menggunakan narkoba & 17 & 12,2 & 122 & 87,8 \\
\hline Makan teratur dan bergizi & 132 & 95,0 & 7 & 5,0 \\
\hline Melakukan olahraga secara teratur & 134 & 96,4 & 5 & 3,6 \\
\hline Memeriksa kondisi kesehatan ke pelayanan kesehatan & 137 & 98,6 & 2 & 1,4 \\
\hline Rerata Perilaku Pencegahan HIV/AIDS & 110,6 & 79,6 & 28,4 & 20,4 \\
\hline
\end{tabular}

Tabel 3. Hubungan antara Pengetahuan, Sikap dan Perilaku Pencegahan HIV/AIDS pada Siswa di SMPN 251 Jakarta, 2019

\begin{tabular}{|c|c|c|c|c|c|c|c|}
\hline \multirow[t]{3}{*}{ Pengetahuan dan Sikap Siswa } & \multicolumn{6}{|c|}{ Perilaku Pencegahan HIV/AIDS } & \multirow{3}{*}{$\begin{array}{c}\text { Nilai } \\
\mathbf{P}\end{array}$} \\
\hline & \multicolumn{2}{|c|}{ Baik } & \multicolumn{2}{|c|}{ Kurang Baik } & \multicolumn{2}{|c|}{ Total } & \\
\hline & Jumlah & $\%$ & Jumlah & $\%$ & Jumlah & $\%$ & \\
\hline \multicolumn{8}{|l|}{ Pengetahuan } \\
\hline - Tinggi & 123 & 94,6 & 7 & 5,4 & 130 & 100 & 1,000 \\
\hline - Rendah & 9 & 100 & 0 & 0 & 9 & 100 & \\
\hline \multicolumn{8}{|l|}{ Sikap } \\
\hline - Positif & 130 & 98,5 & 2 & 1,5 & 132 & 100 & 0,000 \\
\hline - Negatif & 2 & 28,6 & 5 & 71,4 & 7 & 100 & \\
\hline
\end{tabular}

pencegahan HIV/AIDS baik (28,6\%). Hasil uji Chi-Square didapatkan $\rho$ value $=0,000(<0,05)$, disimpulkan terdapat hubungan yang bermakna antara sikap dan perilaku siswa dalam pencegahan HIV/AIDS.

\section{Pembahasan}

Hasil penelitian menunjukkan, sebagian besar responden berpengetahuan tinggi dan bersikap positif terhadap HIV/AIDS. Masih ada informasi tentang stigma yang belum dimengerti responden. Hal ini menunjukkan, responden belum memahami bahwa orang dengan HIV/AIDS tetap memiliki kebebasan dan hak yang sama dan orang dengan HIV/AIDS tidak boleh didiskriminasi karena mereka sama dengan orang pada umumnya.

Penelitian ini sejalan dengan penelitian yang dilakukan oleh Tampi et al. (2013) di SMA Manado International School dengan jumlah responden 120 siswa yang menunjukkan, mayoritas tingkat pengetahuan responden sudah baik tentang tindakan pencegahan HIV/AIDS dengan jumlah 84 responden 84 siswa (70\%). Mayoritas responden bersikap positif tentang tindakan pencegahan 
dengan jumlah responden 77 siswa $(64,2 \%) .{ }^{10}$

Perilaku adalah semua kegiatan atau aktivitas manusia, baik yang dapat diamati langsung maupun tidak langsung. Perilaku yang didasari oleh pengetahuan dan kesadaran akan bersifat menetap, sedangkan perilaku sebaliknya bersifat sementara. Teori perilaku mengatakan bahwa sikap mempengaruhi perilaku seseorang lewat suatu proses pengambilan keputusan yang teliti dan beralasan, dampaknya terbatas hanya pada tiga hal yakni : (1) Perilaku tidak banyak ditentukan oleh sikap umum, tetapi oleh sikap spesifik terhadap sesuatu; (2) Perilaku dipengaruhi bukan hanya oleh sikap, juga oleh norma subjektif, yaitu keyakinan mengenai apa yang orang lain inginkan agar kita perbuat; dan (3) sikap terhadap perilaku bersama norma subjektif akan membentuk suatu intensi untuk berperilaku tertentu. ${ }^{8}$

Hasil penelitian menunjukkan bahwa tidak ada hubungan yang bermakna antara pengetahuan dan perilaku siswa dalam pencegahan HIV/AIDS, tetapi terdapat kaitan yang bermakna antara sikap dan perilaku siswa dalam pencegahan HIV/ AIDS. Hasil ini sejalan dengan teori Notoatmodjo (2014), yang menyatakan bahwa pengetahuan dan sikap berhubungan searah dengan perilaku. ${ }^{8}$ Juga penelitian Rupilu, et al (2014), yang menyatakan, tidak ada kaitan antara pengetahuan dan tindakan pencegahan, tetapi terdapat hubungan antara sikap dan tindakan pencegahan HIV/AIDS pada siswa SMA Negeri I Tual. ${ }^{11}$ Hasil ini sejalan dengan penelitian Manafe et al. (2014) yang menunjukkan, ada kaitan antara pengetahuan dan tindakan pencegahan HIV/AIDS pada siswa di SMA Negeri 4 Manado. $^{12}$

Berbeda dengan penelitian Irsyad, et al. (2015) yang menyatakan, tidak ada hubungan antara pengetahuan dan perilaku pencegahan HIV/AIDS $(\mathrm{p}=0,174)$, serta tidak ada kaitan antara sikap dan dan perilaku pencegahan HIV/AIDS pada remaja komunitas anak jalanan di kabupaten Kudus $(\mathrm{p}=$ 1,476). ${ }^{13}$

Pengetahuan dan sikap remaja yang relatif baik terhadap perilaku pencegahan HIV/AIDS di Indonesia, khususnya pada anak sekolah, seharusnya dapat mengurangi angka kejadian HIV/AIDS di Indonesia, terutama di Pulau Jawa. Namun, data Kemenkes RI (2017) menunjukkan, angka kejadian
HIV masih tinggi di Pulau Jawa, khususnya di Jawa Timur, Jawa Barat, dan DKI Jakarta.

\section{Kesimpulan}

Mayoritas responden berpengetahuan tinggi tentang HIV/AIDS, bersikap positif terhadap HIV/ AIDS, dan perilaku pencegahan yang baik pada HIV/AIDS. Tidak ada hubungan yang bermakna antara pengetahuan dan perilaku pencegahan HIV/ AIDS, tetapi ada hubungan yang bermakna antara sikap dan perilaku pencegahan HIV/AIDS.

\section{Saran}

Guru bimbingan konseling di SMPN 251 Jakarta diharapkan dapat memberikan fasilitas pendidikan kesehatan reproduksi, khususnya terkait HIV/AIDS, kepada siswa-siswi melalui penyuluhan dan bimbingan konseling yang sudah ada. Selain itu, peran wali kelas atau guru yang mengajar di kelas agar dapat memberikan edukasi tambahan kepada siswa-siswi mengenai penularan dan stigma HIV/ AIDS agar siswa-siswi paham dan dapat menerapkan perilaku pencegahan HIV/AIDS secara nyata.

Di samping itu pihak sekolah diharapkan bisa bekerja sama dengan petugas kesehatan sekitar seperti puskesmas untuk mengadakan program UKS di sekolah dalam mengembangkan kebiasaan hidup sehat yang dilakukan secara terpadu. Ini dapat dilakukan dengan memberikan pendidikan kesehatan sehingga pengetahuan siswa-siswi meningkat, membentuk sikap dan perilaku siswasiswi yang lebih baik agar dapat terhindar dari halhal negatif karena lokasi SMPN 251 Jakarta yang dekat dengan kawasan prostitusi. Sekolah juga dapat bekerja sama dengan pemerintah setempat, seperti RT, RW, lurah dan camat, dalam merelokasi daerah prostitusi dan membuka atau membantu mencarikan pekerjaan yang halal bagi para pekerja di tempat prostitusi.

Peran orang tua dibutuhkan dalam pencegahan HIV/AIDS, dengan memberikan kasih sayang dan perhatian kepada anaknya sehingga anak tidak terjerumus dalam mencari kesenangan atau perhatian secara tidak baik, seperti pergaulan bebas dan hubungan seks bebas. Perhatian kecil sangat diperlukan bagi remaja, seperti makan bersama, menanyakan kesulitan di sekolah, menjadi teman berbagi cerita dan menghabiskan waktu bersama 
(rekreasi bersama keluarga).

\section{Ucapan Terima Kasih}

Penulis menyampaikan ucapan terima kasih kepada Kepala SMPN 251 Jakarta, yang sudah memberikan izin lokasi penelitian; guru SMPN 251, yang membantu dalam pengumpulan data penelitian, dan Prof. Sudibyo Supardi, yang telah membimbing penulisan makalah ini.

\section{Daftar Rujukan}

1. Kementerian Kesehatan. Peraturan Menteri Kesehatan Republik Indonesia Nomor 21 Tahun 2013 Tentang Penanggulangan HIV dan AIDS. Tahun terbit $2013(4,7,8)$

2. World Health Organization. HIV/AIDS. 2017 [diakses pada tanggal 15 Juni 2018] publisher. Available from http://www.who.int/news-room/ fact-sheets/detail/HIV-AIDS

3. Kementerian Kesehatan RI. Laporan situasi perkembangan HIV-AIDS \& Penyakit Menular Seksual di Indonesia Januari-Maret (PIMS) Triwulan I Tahun 2017. Jakarta: DITJEN P2P KEMENTERIAN KESEHATAN RI 2017 [diakses pada tanggal 2 Agustus 2018]. Tersedia dalam http://siha.depkes.go.id/portal/files upload/Laporan_HIV/AIDS_TW 1.2017 rev. pdf

4. Kementerian Kesehatan RI. Situasi penyakit HIV-AIDS di Indonesia 2016. Jakarta: Pusat Data dan Informasi Kementerian Kesehatan Republik Indonesia; 2016 [diakses pada tanggal 11 Juni 2018]. Tersedia dalam http://www.pusdatin. kemkes.go.id/article/view/17020100001/ situasi-penyakit-hiv-aids-diindonesia.html

5. Ratnasari ED. Hari AIDS sedunia: 70 persen infeksi HIV akibat seks berisiko [internet]. CNN Indonesia. Tanggal publikasi 27 Nov 2017 [diakses pada tanggal 2 Agustus 2018]. Tersedia pada https:/www.cnnindonesia.com/ gaya-hidup/20171004090958-255-245980/hariaids-sedunia-70-persen-infeksi-hiv-akibat-seksberisiko

6. Dinas Kesehatan Provinsi DKI Jakarta. Data kasus HIV di DKI Jakarta sd Desember 2017. 2017 [diakses pada tanggal 23 Juni 2018] publisher. http://www.fast-trackcities.
org/sites/default/files/Data $\% 20$ Kasus $\% 20$ HIV\%20di\%20DKI\%20Jakarta\%20sd\%20 Desember\%202017\%20-\%20AIDS\%20 Commission\%20for\%20Jakarta\%20.pdf

7. Rahmati, Fafi and Kurniawati, Fitriana H. Hubungan tingkat pengetahuan tentang HIV/ AIDS dengan sikap terhadap pencegahannya pada siswa Kelas X dan XI di SMA Taman Madya Jetis Yogyakarta [Skripsi]. Sleman: STIKES 'Aisyiyah Yogyakarta; 2014

8. Notoatmodjo S. Ilmu Perilaku Kesehatan. Jakarta: Rineka Cipta. 2014.

9. Dinas Kesehatan Provinsi Jawa Barat. Modul pelatihan deteksi dini pencegahan, dan penanganan HIV \& AIDS pada perempuan untuk perawat kesehatan masyarakat. Bandung: Jawa Barat. 2011.

10. Tampi D, Grace D. Kandou, Gustaaf E.A, Ratag †. Hubungan pengetahuan, sikap dengan tindakan pencegahan HIV/AIDS pada siswa SMA Manado International School. Jurnal Kedokteran Komunitas dan Tropik. 2013; 1(4): 140-145.

11. Rupilu NM, Maramis FR, Woodford BS. Hubungan antara pengetahuan dan sikap tentang HIV/AIDS dengan tindakan pencegahannya pada siswa SMA Negeri I Tual. Fakultas Kesehatan Masyarakat Universitas Sam Ratulangi. 2014 [diakses pada 1 Agustus 2018]. Tersedia pada: https://www.academia. edu/10254604/HUBUNGAN_ANTARA_ PENGETAHUAN_DAN_SIKAP_TENTANG_ HIV_AIDS_DENGAN_TINDAKAN PENCEGAHANNYA_PADA_SISWA_SMA_ NEGERI_I_TUAL

12. Manafe LA, Kandou GD, Posangi J. Hubungan antara pengetahuan, sikap, peran Guru, media informasi (Internet) dan peran teman sebaya dengan tindakan pencegahan HIV/AIDS pada siswa di SMA Negeri 4 Manado. JIKMU. 2014; 4(4): 644-655.

13. Irsyad C, Setiyadi NA, dan Wijayanti AC. Hubungan antara pengetahuan dan sikap dengan perilaku pencegahan HIV/AIDS pada remaja komunitas anak jalanan di Kabupaten Kudus. Fakultas Ilmu Kesehatan Universitas Muhammadiyah Surakarta. 2015. 